\title{
Cross Reaction of Haemonchus contortus Protein with Toxocara vitulorum Anti-L2 Serum Using Western Blot Technique
}

\author{
Rani Wilujeng Asmorowati ${ }^{1}$ Kusnoto $^{1^{*}}$, and Hana Eliyani ${ }^{2}$ \\ ${ }^{1}$ Department of Veterinary Parasitology, Faculty of Veterinary, Universitas Airlangga, Surabaya-60115, Indonesia \\ ${ }^{2}$ Department of Veterinary Anatomy, Faculty of Veterinary, Universitas Airlangga, Surabaya-60115, Indonesia \\ *Corresponding author's Email: kk.kusnoto@yahoo.com; (DORCiD: 0000-0003-3915-654X
}

\begin{abstract}
In the adult stage, Haemonchus contortus worms infect the abomasum host causing anemia and even death in animals. However, identifying the $H$. contortus protein can be used as a reference for the diagnosis of diseases. The diagnosis is performed by serological cross-reaction between $H$. contortus protein and anti-L2 Toxocara vitulorum (T. vitulorum) serum using the western blot technique. The main purpose of the current research was to identify the cross-reaction between $H$. contortus proteins and anti-L2 T. vitulorum serum using the western blot technique. $T$. vitulorum worms were collected from the intestine of cattle and $H$. contortus worms were collected from the abomasum of goats. The first step was making antibodies by oral infection of rats with infective eggs (L2) of $T$. vitulorum. The blood was taken 21 days after infection. Then, the blood was centrifuged at $1500 \mathrm{rpm}$ for 10 minutes to get the serum. The second step was making homogenates from the whole worm extract of $H$. contortus. After crushing the worms, it was centrifuged at $5000 \mathrm{rpm}$ for 15 minutes and the supernatant was taken. The supernatant was then analyzed using Sodium Dodecyl Sulphate Polyacrylamide Gel Electrophoresis (SDS-PAGE) with coomassie brilliant blue staining. The third step was the analysis of $H$. contortus protein with serum anti-L2 $T$. vitulorum using the western blot technique. From the $H$. contortus homogenates analysis using SDS-PAGE, 16 protein bands were obtained. The cross-reactions were 141.3, 81.3, 64. 6, 51.3, 46.8, and $38 \mathrm{kDa}$. The data from cross-reactions suggested that the $H$. contortus protein cannot be used as a diagnostic material. It is serologically Haemonchosis because it caused false positives with diagnostic Toxocariasis.
\end{abstract}

Keywords: Cross reaction, Haemonchus contortus, SDS-PAGE, Toxocara vitulorum, Western blot

\section{INTRODUCTION}

Haemonchosis is a parasitic disease caused by a nematode worm infection from the family of Trichostrongylidae and Haemonchus genus. The main cause of haemonchosis is Haemonchus contortus (H. contortus) worm. In the adult stage, this worm infects the abomasum of the host, causing anemia that leads to death (Githigia et al., 2001). Meanwhile, Toxocara vitulorum (T. vitulorum) is a pathogenic worm in ruminants. Their definitive hosts are buffaloes and they live as an adult within the small intestine lumen of ruminants (Abdelrahman and El-Menyawe, 2015). They can also be found in the calves of bulls (Van der Steen et al., 2014).

The conventional diagnosis of nematodes shows positive results if the infection has passed the prenatal stage (1316 weeks). The effort which can be done to overcome the problem in diagnosis is developing a sensitive diagnostic technique based on serological examination. Serological testing using ELISA can be used to diagnose the disease. However, this technique has a disadvantage; If the antigen used is not specific, then the test's specificity will be in the low range (Sackey et al., 2003).

The $H$. contortus is the most dangerous and most observed worm in Southeast Asia, including in Indonesia; In North Sumatra, the prevalence of livestock infected by H. contortus has reached $40 \%$ (Silva et al., 2008). In Nigeria, the prevalence of toxocariasis due to T. vitulorum infection in calves is 61.4-91.1\% (Sackey et al., 2003). Haemonchosis is a significant threat in tropical, subtropical, and warm regions as warm and moist conditions are favorable for the freeliving stages (Besier et al., 2016; Fentahun, 2020). Worm-infected cases result in economic losses because of the decrease in animal productivity, weight loss, diarrhea, and severe cases that even lead to death (Githigia et al., 2001). Conventional diagnosis by finding eggs in a patient's stool is not possible because eggs are only produced by adult worms. For diagnosis, cases of $H$. contortus infected, require an accurate test and one of them is serological testing. Worms are multicellular organisms that have various specific and non-specific proteins that can trigger the host's immune response to form various antibodies so that when a positive diagnosis is made with serological tests, it allows to 
conduct cross-reaction (Sackey et al., 2003). Cross reaction between worm species can cause false positives, but proteins that experience the cross-reaction can be developed as vaccine candidates. In proteins that are not cross-reactions, further detentions and evaluations can be carried out on the specificity of the worm antigen (Abdel-Rahman and Abdel Megeed, 2000). Identification of specific proteins plays an important role, which can be used as a reference for the diagnosis of disease. One of the tests recommended to confirm the diagnosis is the serological test. The main principle of serological tests is to react to antigens with appropriate antibodies. In the case of infection, it will result in antibodies that are dissolved in the serum. The formed antibodies will circulate throughout the tissues and blood circulation. The body will mobilize B lymphocyte cells which will differentiate into plasma cells, during the time it deals with infectious agents. Plasma cells will produce antibodies. If the antibodies find an antigen, then the antigen will be bound by antibodies (Slifka and Amanna, 2019).

The present study evaluated $H$. contortus protein along with anti-L2 $T$. vitulorum serum using Western blot technique. This study was conducted to determine the cross-reactions that can occur in worms of the same class, but in different species that were $H$. contortus and $T$. vitulorum. This study aimed to detect blood mononuclear (BM) $H$. contortus proteins that could bind to anti-L2 T. vitulorum serum using Western blot techniques.

\section{MATERIALS AND METHODS}

The current study was a laboratory exploratory study aimed at describing BM $H$. contortus proteins undergoing crossreaction with anti-L2 T. vitulorum serum. The study was conducted at the Parasitology Laboratory of Universitas Airlangga and the Institute of Tropical Disease (ITD), Surabaya, Indonesia, from July until November 2016.

The sample collection process from the intestine of cattle and the abomasum of goats was in accordance with animal ethic regulations announced by the Airlaanga University Ethical committee.

\section{Collection of Haemonchus contortus and Toxocara vitulorum}

The $H$. contortus worms were obtained from goat abomasum and $T$. vitulorum worms were taken from the small intestine of male cows. The collected worms were separated from the stool and immediately cleaned using Phosphate Buffer Saline (PBS). The cleaned worms were put in a petri dish containing PBS and then incubated in an incubator at $37^{\circ} \mathrm{C}$ (Kusnoto et al., 2011).

\section{Isolation of L2 Toxocara vitulorum}

Adult T. vitulorum worms were incubated for three days in an incubator at $37^{\circ} \mathrm{C}$ to produce eggs. After three days, the eggs of $T$. vitulorum worm were surgically taken from the reproductive tract. Afterwards, the worm eggs were identified, then fertilized in PBS medium at room temperature for 28 days to obtain T. vitulorum L2 (Kusnoto et al., 2011).

\section{Calculation of worm eggs per gram stool}

In the current study, egg counting was performed by modifying the calculation of worm eggs per gram stool using the Lucient Brumpt method. Based on the calculation, to identify the number of T. vitulorum eggs in each ml suspension of culture media, the following formula was used. The number of drops per $\mathrm{ml}(\mathrm{N}) \times$ number of worm eggs per drop (n) $\times$ number of dilutions (Lindstrom, 2003).

\section{Treatment of experimental animals}

The experimental animals used in this research were five male rats aged two months old. The rats were infected with L2 T. vitulorum at a dose of 10 grains per gram of body weight orally (Kusnoto et al., 2011). Before being infected, the rats were adapted for seven days. After adaptation, the rats were infected with L2 T. vitulorum. The purpose of this artificial infection was to obtain a serum containing L2 T. vitulorum antibodies.

\section{Blood sampling of rats}

The blood of the rats was taken 21 days after infection by cutting the rat's tail. The blood was inserted into a microtube, centrifuged at $1500 \mathrm{rpm}$ for 10 minutes to get the serum (Lee and Goosens, 2015).

\section{Preparation of Haemonchus contortus homogenate}

Homogenate was made manually by grinding $H$. contortus worms with a mortar, then it was inserted into the test tube and suspended with $3 \mathrm{ml}$ PBS. The suspension was then centrifuged at $5000 \mathrm{rpm}$ for 15 minutes. Pellets and supernatants were separated. Supernatants were stored for protein analysis with SDS-PAGE and western blotting. Running was conducted on the results using the SDS-PAGE technique (Lindstrom, 2003).

\section{Protein analysis using the SDS-PAGE technique}

During SDS-PAGE technique, the protein electrophoresis was done in an ionic detergent which was Sodium Dodecyl Sulfate (SDS). One of the systems in SDS is discontinuation (Laemmli). In this system, protein migrates rapidly through ion solvents on stacking gel and separating gel. Protein is concentrated in a thin band line (Lindstrom, 2003). 


\section{Characterization of proteins using Western blot technique}

From the homogenate of $H$. contortus worms which has gone by the running gel process using SDS-PAGE, gel with protein fragments was obtained based on BM. In this process, the protein can be directly transferred to the nitrocellulose membrane using the Bio-rad model. The transfer of protein from the gel to nitrocellulose membrane was carried out by the Electrophoresis technique (Lindstrom, 2003).

\section{Calculation of protein molecular weight}

The Relative Molecular mass (MR) of the antigen protein was determined by a regression equation method. It was based on the value of the Retardation factor (Rf) of each band formed by using the western blot technique according to the method of Miletić and Saracević (1984). The MR was determined based on the MR log of the standard protein and the Rf value. Then, the equation was obtained by determining the standard curve of Rf and log MR (Lindstrom, 2003).

The molecular weight of an antigen or antibody was obtained by calculating the Rf value of each band (band) with the following formula:

\section{$\boldsymbol{R} \boldsymbol{f}=\underline{\text { Migration distance of the protein }}$ \\ Migration distance of the dye front}

Where, distance refers to the distance of protein movement from the initial place, and Length is the distance of color movement from the starting point (dye front).

The relative molecular mass of protein was determined by converting the $\mathrm{Rf}$ value data and the relative molecular mass of standard protein to an equation. The logarithmic value of the relative molecular mass of standard proteins indicated the function $\mathrm{Y}$, while $\mathrm{X}$ is the value of $\mathrm{Rf}$. After the Rf value of the sample was found, it was entered into the equation. Furthermore, based on the results of the equation, the anti-log value was obtained to get the relative molecular mass value of protein (Kusnoto et al., 2011).

\section{RESULTS AND DISCUSSION}

\section{Collection and identification of Haemonchus contortus worms}

The $H$. contortus worms were obtained from the goat abomasum. $H$. contortus worms have a very small body size. Male $H$. contortus worms are 10-20 mm in length and red color, while female worms are 18-30 mm in length and red and white colors (it is known as barber's pole). The color produced by the variation of ovaries and intestines is red because of the blood sucked from the host. Identification of $H$. contortus worms is based on their reproductive organs. Male $H$. contortus worms have dorsal rays that are shaped like "Y" and spicules with 0.46-0.506 mm length (Figure 1). In female worms, the vulvars are covered by large and prominent flaps (Vulva flap). Male and female $H$. contortus have been demonstared in Figure 2.

\section{Collection and identification of Toxocara vitulorum worms}

The $T$. vitulorum worms were collected from the small intestine of adult male cows. The male T. vitulorum worms are $15-26 \mathrm{~cm}$ in length and 3-5 mm diameter with a small tail and female $T$. vitulorum worms are $22-30 \mathrm{~cm}$ in length with 5-6 mm diameter. Female $T$. vitulorum worms have thin, soft, and transparent cuticles. The identification of the $T$. vitulorum worms is based on the length of the body and the presence of its reproductive organ (Figure 3 ).

\section{Collection of L2 Toxocara vitulorum}

The eggs of T. vitulorum are subglobular and brownish. The eggs have thick spotted walls. Stage II (L2) larvae were found in ineffective worm eggs. The details are presented in Figure 4.

\section{Protein analysis using sodium dodecyl sulphate polyacrylamide gel electrophoresis technique}

From the protein analysis of Whole Worm Extract (WWE) of $H$. contortus using SDS-PAGE technique, WWE of $H$. contortus, 16 protein bands were prepared. By running SDS-PAGE on WWE of H. contortus, 16 proteins bonds with the following BM 141.3, 117.5, 81.3, 64.6, 51.3, 46.8, 42.7, 38, 34.7, 29.5, 26.9, 23.4, 20.9, 15.5, 12.9, and 11.7 kDa were obtained.

\section{Protein characterization using western blot technique}

The results from WWE of $H$. contortus analyzed proteins which were reacted with anti-L2 T. vitulorum serum by western blot technique indicated that the WWE of $H$. contortus bounded to anti-L2 T. vitulorum serum on BM 141.3; $81.3 ; 64.6 ; 51.3 ; 46.8$ and $38 \mathrm{kDa}$. 


\section{Results of protein analysis using sodium dodecyl sulphate polyacrylamide gel electrophoresis technique}

In SDS-PAGE, the protein is electrophoresed in ionic detergent and SDS. In the discontinuous system (Laemmli), proteins migrate rapidly through ion solvents on stacking gel and separating gel. The protein will be concentrated on a thin line in the form of a thin band (Slifka and Amanna, 2019). In the current study from the results of WWE of $H$. contortus protein analysis, 16 kinds of protein bands with the BM of 141.3, 117.5, 81.3, 64.6, 51.3, 46.8, 42.7, 38, 34.7, $29.5,26.9,23.4,20.9,15.5,12.9$, and $11.7 \mathrm{kDa}$ were obtained. Meanwhile, from the identification of the other WWE of H. contortus, 16 protein bands included the BM of 107.74, 64.68, 51.39, 47.1, 43.52, 38.55, 36.27, 32.97, 28.95, 25.8, $25.8,23.25,20.95,15.65,12.85$, and $9.93 \mathrm{kDa}$. Protein bands that were similar to those obtained in this study included $64.6,51.3,38,23.4,20.9,15.5$, and $12.9 \mathrm{kDa}$. The difference was related to the calculation and possible relative differences in determining the distance of the protein band and the length, as well as the beginning of the measurement of the gel. It is possible that several protein bands had some differences with the results of other studies (Santos et al., 2014; Tak et al., 2015), but they referred to the same protein (Kusnoto et al., 2011).

The SDS-PAGE is the commonly used analytical method for resolving components of a protein mixture (Grabski and Novagen, 2001). Observations on protein analysis using the SDS-PAGE technique indicated that the success rate of the analysis was influenced by three factors, including homogenate cleanliness, homogenate purity level, and protein content in homogenates. Hygiene cleanliness affects the quality of protein bands formed in the gel where the ribbon could look sharply colored on a bright gel, thus allowing protein analysis and documentation. This technique is also a powerful tool for estimating the molecular weights of proteins (Grabski and Novagen, 2001).

\section{Characterization of proteins using western blot technique}

The $H$. contortus and $T$. vitulorum are worm pathogens because they attack internal organs and cause diarrhea in animals and in case the infected animal is not treated intensively, it will even die. One of the techniques that can determine the presence of antigen reactions with antibodies is blotting. Blotting is a technique for transferring macromolecules from the gel medium onto the membrane after the Electrophoresis process. Separate bands can be detected by coloring. The blotting technique is used to detect proteins, carbohydrates, and enzyme activity. One of the used blotting techniques is Western blot.

The basic principle of the Western blot technique is to separate proteins by SDS-PAGE, then transfer the proteins to the appropriate nitrocellulose membrane, followed by labeling the proteins with antibodies and visualizing them by the desired coloring, such as coomassie blue (Slifka and Amanna, 2019). Cross-reactions occurred between H. contortus protein and anti-L2 T. vitulorum serum on BM 141.3, 81.3, 64.6, 51.3, 46.8, and $38 \mathrm{kDa}$. The presence of a crossreaction indicated that the protein is not a good diagnostic agent for haemonchosis because it causes false positives with diagnostic Toxocariasis.

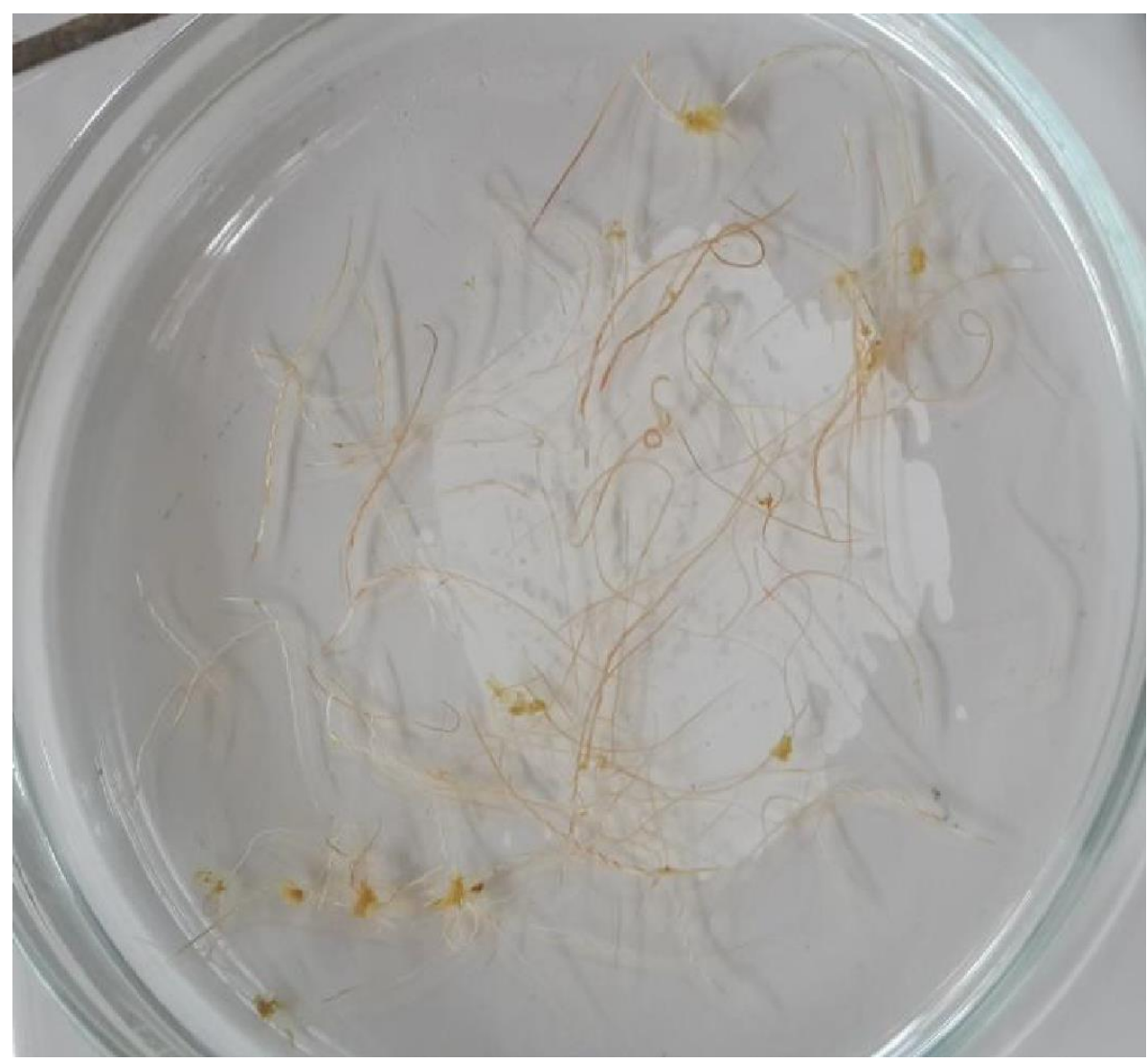

Figure 1. Adult stage of Haemonchus contortus 

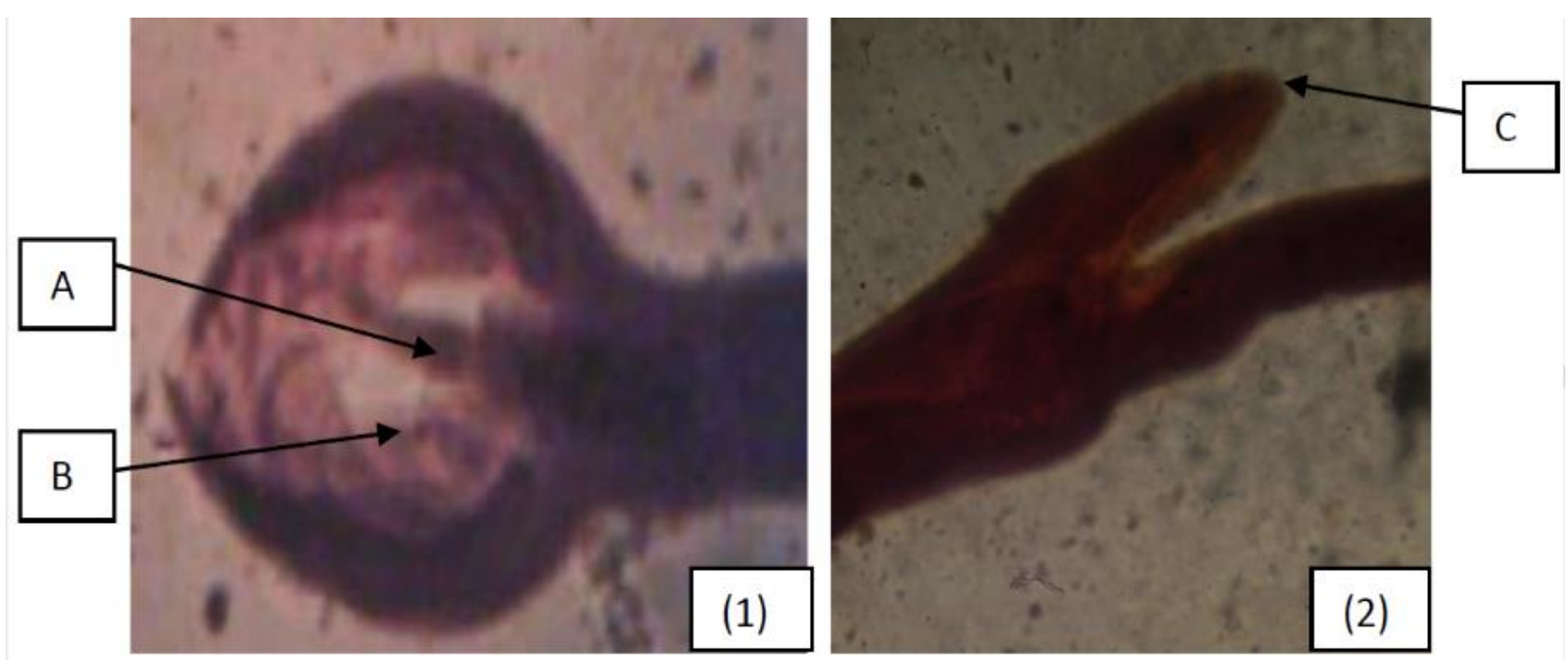

Figure 2. Identification of male and female $H$. contortus worms. Male worms (1), A is Spikula and B is dorsal rays. Female worms (2), part of $\mathrm{C}$ is vulva flap. The observation was done by using $40 \times$ magnification.

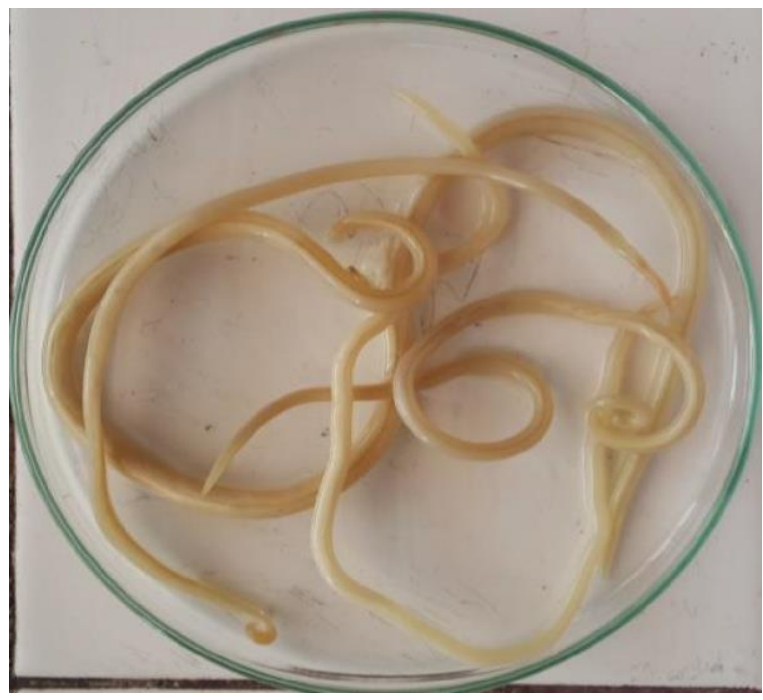

Figure 3. Adult Toxocara vitulorum worms

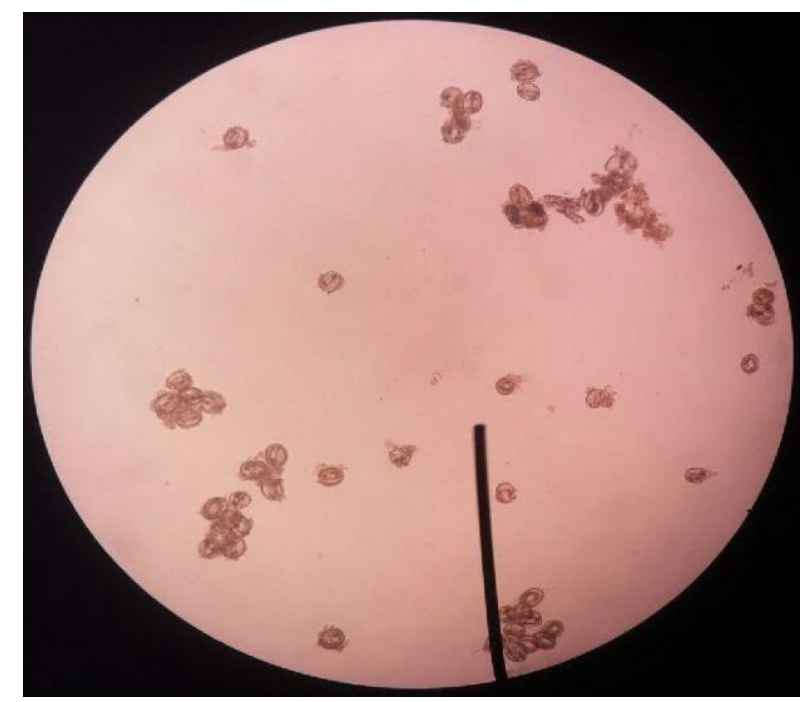

Figure 4. L2 Toxocara vitulorum (100× magnification).

\section{CONCLUSION}

In this research, cross-reactions between Haemonchus contortus protein and anti-L2 Toxocara vitulorum serum on BM of 141.3, 81.3, 64.6, 51.3, 46.8, and $38 \mathrm{kDa}$ were obtained. The anti-L2 T. vitulorum serum can recognize antigens from Haemonchus contortus, Moniezia benedeni, and Toxocara canis on proteins with the same BM of $38 \mathrm{kDa}$. The presence of a cross-reaction indicates that the protein is not a good diagnostic agent for haemonchosis because it causes false positives with diagnostic toxocariasis.

\section{DECLARATIONS}

\section{Authors' contribution}

R. Wilujeng Asmorowati, Kusnoto, and H. Eliyani contribute equally in conduction, analysis, and writing of the manuscript. The authors checked and confirmed the final version of article.

\section{Competing interests}

The authors have no conflict of interests

\section{Ethical considerations}

Ethical issues (including plagiarism, consent to publish, misconduct, data fabrication and/or falsification, double publication and/or submission, and redundancy) have been checked by the authors. 


\section{REFERENCES}

Abdel-Rahman EH, and Abdel Megeed KN (2000). Molecular identity of major cross-reactive adult antigens in Fasciola gigantica, Toxocara vitulorum and Moniezia expansa. Journal of Egyptian Society of Parasitology, 30(2): 561-572. Available at: https://pubmed.ncbi.nlm.nih.gov/10946516/

Abdelrahman M, and El-Menyawe SM (2015). A Review of Toxocariasis in man and animal. Egyptian Journal of Chemistry Environment and Health, 1(1): 315-330. Available at: http://cehea.org/wp-content/uploads/2016/08/23-.pdf

Besier RB, Kahn LP, Sargison ND, and van Wyk JA (2016). Diagnosis, treatment and management of Haemonchus contortus in small ruminants. Advances in Parasitology, 93: 181-238. DOI: https://www.doi.org/10.1016/bs.apar.2016.02.024

Fentahun T (2020). Systematic review on gastrointestinal helminthes of domestic ruminants in Ethiopia. Online Journal of Animal and Feed Research, 10(5): 216-230. DOI: https://www.dx.doi.org/10.51227/ojafr.2020.31

Githigia SM, Thamsborg SM, Munyua WK, and Maingi (2001). Impact of gastrointestinal helminths on production in goats in Kenya. Small Ruminant Research, 42(1): 21-29. DOI: https://www.doi.org/10.1016/S0921-4488(01)00240-1

Grabski AC, and Novagen RRB (2001). Preparation of protein samples for SDS-polyacrylamide gel electrophoresis: Procedures and Tip. Novations 13, Madison- Wisconsin, pp. 10-12. Available at: http://citeseerx.ist.psu.edu/viewdoc/summary?doi=10.1.1.378.613

Kusnoto SS, Sudiana IK, and Koesdarto S (2011). Karakteristik dan isolasi protein spesifik dari material excretory-secretory (ES) toxocara cati untuk pengembangan diagnostik toxocariasis dengan teknik ELISA. Jurnal Biosains Pascasarjana, 13(1): 56-65. Available at: http://journal.unair.ac.id/download-fullpapers-Vol\%2013\%20No\%201\%20Jan\%202011-7.pdf

Lee G, and Goosens KA (2015). Sampling blood from the lateral tail vein of the rat. Journal of Visualized Experiments, (99): e52766. DOI: https://www.doi.org/10.3791/52766

Lindstrom R (2003). Epidemiology of Brucellosis. Office Internationale des Epizooticae, Universitas Airlangga Press, Surabaya, Indonesia, pp. 112-120.

Miletić VD, and Saracević M (1984). Isolation and determination of the molecular mass of the RHoD antigen in human erythrocytes. Bilten za Hematologiju i Transfuziju, 12(2): 51-58. Available at: https://pubmed.ncbi.nlm.nih.gov/6441566/

Sackey AKB, George JBD, and Sale M (2003). Observation on the age at initial infection of Zebu calves by Toxocara vitulorum in Northern Nigeria. Tropical Veterinarian, 21(3): 124-128. DOI: https://www.doi.org/10.4314/tv.v21i3.4531

Santos MC, Amarante MR, Silva MR, and Amarante AF (2014). Differentiation of Haemonchus placei from Haemonchus contortus by PCR and by morphometrics of adult parasites and third stage larvae. Brazilian Journal of Veterinary Parasitology, 23(4): 495500. DOI: https://www.doi.org/10.1590/S1984-29612014085

Silva BF, Amarante MRV, Kadri SM, Carrijo-Mauad JR, and Amarante AFTD (2008). Vertical migration of Haemonchus contortus third stage larvae on Brachiaria decumbens grass. Veterinary Parasitology, 158: 85-92. DOI: https://www.doi.org/10.1016/j.vetpar.2008.08.009

Slifka MK, and Amanna IJ (2019). Role of multivalency and antigenic threshold in generating protective antibody responses. Frontiers in immunology 10: 956. DOI: https://www.doi.org/10.3389/fimmu.2019.00956

Tak IU, Chishti MZ, and Ahmad F (2015). Protein profiling of Haemonchus contortus found in sheep of Kashmir valley. Journal of parasitic diseases: official organ of the Indian Society for Parasitology, 39(4): 639-644. DOI: https://www.doi.org/10.1007/s12639-014-0433-7

Van der Steen L, Pardon B, Sarre C, Valgaeren B, van Hende D, Vlaminck L, and Deprez P (2014). Intestinal obstruction by Toxocara vitulorum in a calf. Vlaams Diergeneeskundig Tijdschrift, 83(6): 299-305. DOI: https://www.doi.org/10.21825/vdt.v83i6.16628 